\title{
Mechanistic plan and urban mass: two contexts of efficient wedding halls in Turkey
}

\author{
EmreAltürk
}

The efficiency demanded by the modern world affects most areas of life, including the organisation of space. Industrial production is an emblematic field for this phenomenon, having deeply affected architecture and the urban environment. Before industrial production began inspiring modern architecture, the modernisation of expanding European urban fabric in the nineteenth century was mostly driven by the implementation of new transportation infrastructure ensuring the effective functioning of metropolitan areas. The reorganisation of space at all scales and according to a rationale relating to economic drive, industrial production, mass consumption, or scientific management has been the defining characteristic of the modern era, coupled with and in relation to the unprecedented concentration of population, goods, and services. This rationale has since infiltrated, arguably, all spheres of life and has been so internalised by many that it is usually hard to discern.

It has been argued that, despite its pervasiveness, it is in places such as supermarkets, car parks, and factories that the rationale governing the modern metropolis and its inhabitants is unveiled. ${ }^{1}$ In this article, I study wedding halls, a building type one does not immediately associate with being primarily designed for efficiency. I position the buildings within two contexts. Firstly, I relate their workings, which depend on routing users and timing their activities, to historical precedents to demonstrate their kinship to the pragmatic modernist rethinking of the architectural plan as an efficient enabler of human activities. Secondly, I dwell on the architectural typology of the wedding hall in relation to its urban context. I try to show how the pressure for efficiency was put on the design of this emerging building type by the rapidly growing urban masses of the time. Doing so, I follow one of the few early traces that increasing urban density left on architectural design thinking in Turkey.

\section{How to plan a wedding?}

Çankaya Wedding Hall in Ankara serves as a suitable introduction to the subject. It is the first purposebuilt freestanding facility of its kind in the capital, still the most popular in the city and one of the busiest in the country. Moreover, its workings have not changed significantly since it was conceived in 1992. ${ }^{2}$ The building is situated at the corner of a park in the city centre. It has a central and symmetrical plan made up of primary forms: two concentric circles inside a square [1]. The inner circle is the wedding hall. Space between the two circles are foyers on the road side of the building and back-of-house functions, offices, and relevant commercial units on the park side. The rest is mainly semi-open areas underneath the eaves of the square. ${ }^{3}$ It is possible to read how the various actors partaking in the ceremony move within the building by examining the configuration of the plan, provided that one has some familiarity with the cultural context. The couple to be married enter the building through a back entrance facing the park. Here, they take the stairs and go to one of the dressing rooms on the first floor. The wedding guests access the building from the roadside, arrive at the entrance foyer on the central axis of the building, and enter the hall, where they sit and briefly wait for the ceremony. The eccentricity of the wedding hall mainly stems from the fast and effective way in which it facilitates successive weddings by means of its layout, which almost resembles a production line. A peculiar feature of this line are the 'access ramps' on either side of the stage. The couple descend to the stage on one of these ramps from their dressing room on the first floor. They meet the marriage officer and the witnesses on the stage. The official ceremony is quite brief and hardly takes more than five minutes. The marriage officer reiterates a mostly standardised speech, the couple and the witnesses just say that 'they do' when asked. No personal vows or speeches take place. After being declared lawfully wedded spouses, the newlyweds continue to one of the exit foyers on either side of the hall. The audience leave the hall using the side doors and meet the couple at the exit foyer. Here, the guests form a line to congratulate the couple one by one and have their photo taken together. It is also customary to give the couple gifts such as jewellery, 

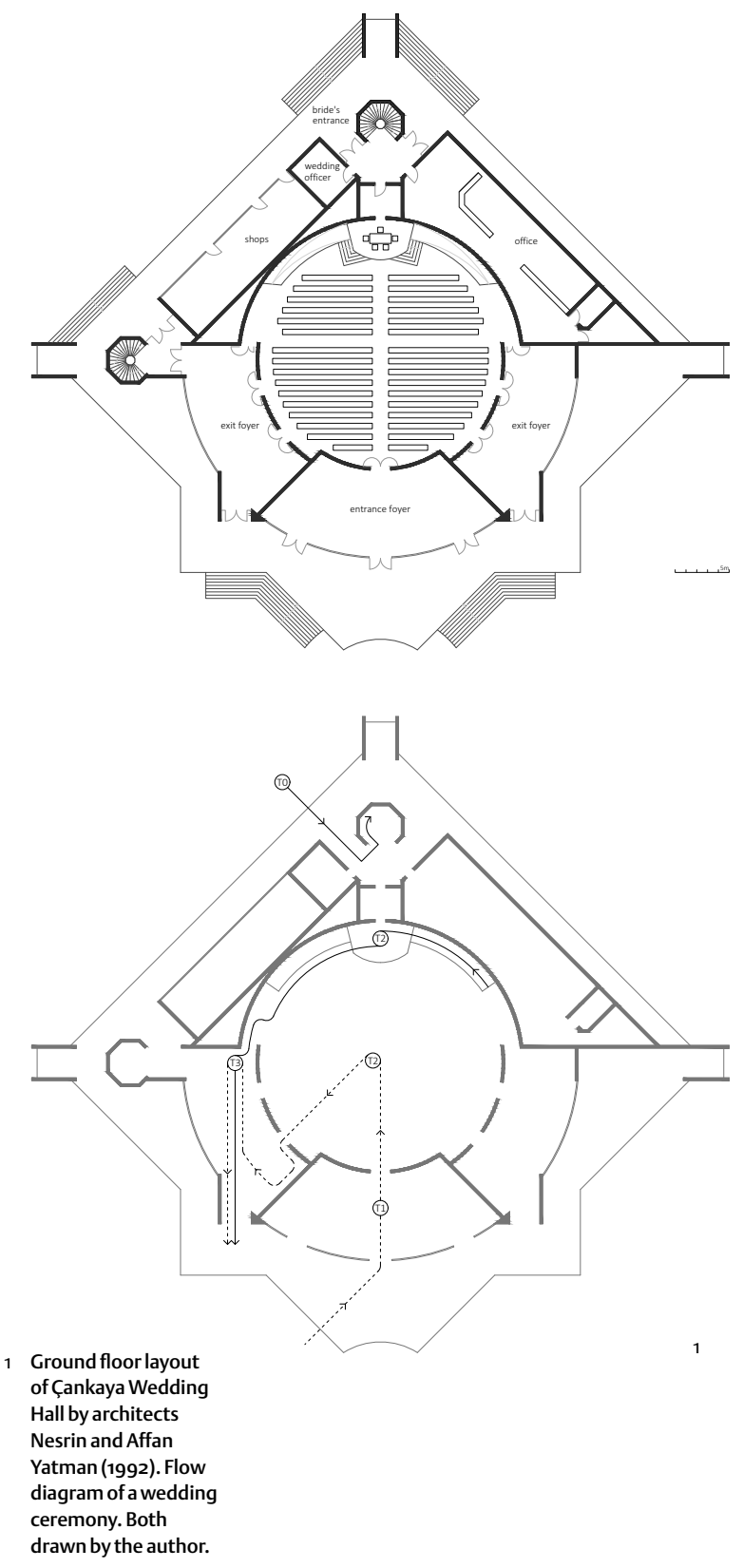

gold coins, or money, which are either put on by the couple or pinned on them. The line moves along and the guests are offered sweets or simple keepsakes in a small pouch on their way out. This final part of the wedding, which may be roughly translated as the 'jewellery ceremony', usually takes more time than the official ceremony on stage. This would have created a problem in terms of efficient use of the main hall if the building did not have twin exit foyers. While the couple accept the congratulations in the first exit foyer, its doors to the main hall are closed. The next group of guests proceed from the entrance foyer to the hall and wait for the next couple to descend from the ramp. After the official ceremony, this second group pass to the other exit foyer, giving the first group time to finish. Interestingly, the building operates this way both when a large number of weddings are officiated in one day, usually summer weekends, and on less popular seasons, such as winter, when the weddings could actually be scheduled more comfortably. ${ }^{4}$ The latter may be a managerial decision, yet the fact that such a capacity is built into the system seems to have encouraged the decision.

The workings of the wedding hall outlined here depend on both the intrinsic capacities of the architectural plan and an unmistakably modern approach towards those capacities. On the former level, the building does what architecture almost always does; it defines and separates spatial units and regulates their relation. In this case, it defines differentiated spaces for the couple and the guests to engage in various tasks simultaneously without coming into contact, then it enables the orchestration of their interaction, and later it allows two groups of people to engage in separate activities in close proximity but safely segregated from each other. This most basic architectural operation is present in almost any building. In its simpler forms, in an apartment or a house, it enables different users to engage in different tasks such as sleeping, working, relaxing, preparing food, showering, usually in specialised, equipped rooms and in relative privacy when need be. In larger and intricate domestic layouts people can circulate separately inside the house without much contact. ${ }^{5}$ Obviously more complex building schemes can accommodate and regulate even radically different activities. For instance, a waiting room can be next to a WC and a surgery room, while having direct access to the former and having no access or a regulated and procedural access to the latter, via changing rooms, semi-sterile, and sterile corridors.

Creating sequential volumes and managing movements and flows within restricted spaces (or via spatial restriction) are just as intrinsic to architecture as the creation of spatial units. The mythological labyrinth of Daedalus serves as a paradigmatic example. Yet the layout of the above-mentioned wedding hall is more akin to a modern deployment of these basic capacities of architecture. Arguably proliferating in the early twentieth century, especially among modernist architects, it is possible to distinguish a more mechanistic approach towards spatial configuration and the human actions within architectural space. This is in part inspired by the factory production lines where the organisation of the production process more or less overlaps with the organisation of space. As such, the function, or in more general terms, activities in space provide a seemingly objective base for design, which partially explains the appeal of industrial methods for modernist architects of functionalist tendency. The projection of users' potential movements in space is, of course, a much larger concern in modernism than just efficiency. For instance, important modernist techniques and notions such as montage or promenade architecture also presuppose the mobile observer and involve designing their experience. Coming back to the deployment of user trajectories in designing for efficiency, there are examples where one specifically sees delineated lines of movement in architectural drawings used to judge and design building layouts on the basis of energy consumption, travel time, ease of motion, and, in general, aptness for purpose. 


\section{Routes on drawings}

The most radical example of such a study is perhaps Alexander Klein's work in the late 1920s. Klein's goal was to come up with objective tools to measure the evaluation criteria for small apartment plans, such as economy, clarity, form, and arrangement of rooms. ${ }^{6}$ He argued that, despite being crucial in terms of the quality and value of a plan, these criteria remained subjective. Klein offered what is called a 'graphical method' that mainly involved delineating the crucial aspects of a plan so as to render them visible, measurable, and comparable. The most significant criterion in terms of determining the layout was efficiency of circulation, which was to be judged by 'pathways'. ${ }^{7}$ These were the lines tracing the routes between various destination points in the apartment, such as beds, the toilet, sofa, and table [2]. The pathways were used as objective tools to measure domestic efficiency quite literally in terms of metres. Working in the context of the Weimar-era Berlin, with its affordable housing shortage and continuous economic crises, Klein's effort was concentrated on minimising floor space. The whole point of the pathway analysis was to attain both the shortest and the straightest lines possible, which would, for Klein,
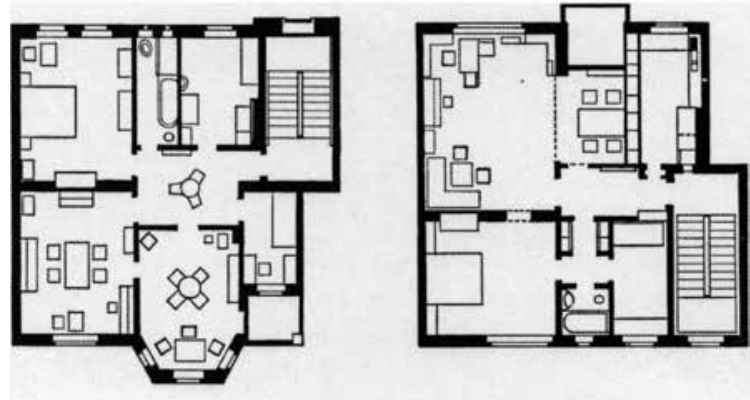

Bad example Good example
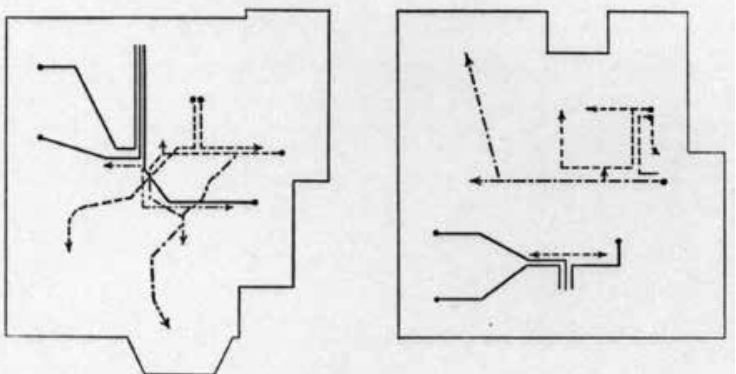

result in the optimal layout. In his comparison of floor plans, the schemes that implicated longer pathways or turns were deemed inferior and less efficient as they would lead to the consumption of more biological energy.

Klein's trajectory lines on the apartment plans resemble electronic circuit diagrams both visually and, in the sense that the imagined inhabitants, like electric current, choose the shortest possible route between two points. They also never touch one another or overlap. The technical look of the drawings and Klein's claim to objectivity are betrayed, however, by the probable multiplicity of routes in any domestic space, even in a modest one. His routes were a selection, leaving many others out, some of which are as basic as the one from the sofa to the bathroom. As Klein argued for a clear separation of the living space from sleeping and services, these two sets of spaces were neatly grouped at opposite sides of Klein's plans, and no pathways connected the two. ${ }^{8}$

There are other, earlier drawings from the 1920s, and by architects as prominent as Eileen Gray and Bruno Taut, of architectural plans that include projected user routes, albeit with less of a technical pretension. ${ }^{9}$ Taut's book, The New Dwelling, The Woman as Creator (1924) included similar comparisons between common apartment plans and improved layouts. ${ }^{10}$ Klein commended this book for promoting a 'simplification of life through better arrangement of the living space and the furniture' and seems to have been inspired by it. ${ }^{11}$ Taut's comparisons depended heavily on the efficiency of the layout, which in turn was visualised and judged by the help of the user routes delineated on the plans. Separation of activities and specialisation of rooms were just as pivotal to the proposed improvements as they would be for Klein later. Taut argued that his suggestions were informed by 'the new household science' that helps transferring a 'Taylorist system to the dwelling. ${ }^{12}$ One of Taut's main references, Christine Frederick, has more readily discernible links to Taylorism. In a series of books published in the 1910s, the American home economist applied the notions of the then-rising scientific management and efficiency engineering, such as time study and motion study, to domestic chores - in other words 'her factory, her business'. ${ }^{13}$ In a schematic drawing published in 1913 and
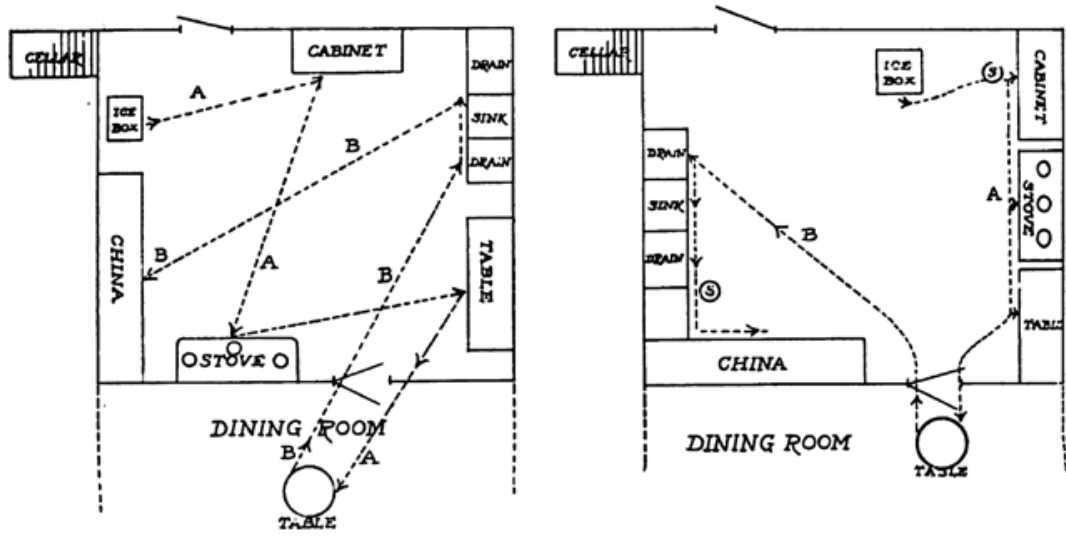

3

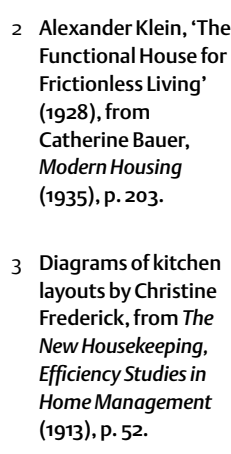

(1913), p. 52. 
reprinted in Taut's book, Frederick showed a proper kitchen layout for efficient food preparation and table clearing, again through a comparison [3]. In the good example, all consecutive steps of preparation and clearing are simply at the next and closest point. The chain of food preparation starts from the icebox and culminates at the table where the chain of clearing starts, which, in turn, end in the china closet. The drawing is stylised so as to convey the smooth succession of steps: straight lines are arranged mostly at forty-five or ninety degrees, joined 'gracefully' by curves, and the diminutive table, perfectly aligned with the door, acts as a 'pulley-like loop' joining the preparation chain and the clearing chain. ${ }^{14}$ In the badly arranged kitchen, lines are much longer, conveying time-consuming walks between each step of the process, intersect at various disorderly angles, and even pass through a wall, implying rapid turns.

Many of Christine Frederick's suggestions may today seem like kitchen tips or 'hacks' rather than 'science' or 'engineering,. ${ }^{15}$ Yet, through a transposition of 'scientific management principles', as developed by Frederick Taylor, and Lillian and Frank Gilbreth, to the domestic tasks, her methods aspired to objectivity. ${ }^{16}$ Frederick's work was received quite enthusiastically when translated and later promoted by architects like Taut in Germany, where rationalisation almost acquired the status of a 'national cult by the end of the twenties'. ${ }^{17}$ As evident in Taut's book, Neuer Haushalt (new housekeeping) was connected to and operational in Neue Wohnung (new dwelling), the rethinking of housing, along the lines of Neues Bauen (new building) or Neue Sachlichkeit (new objectivity). Nicholas Bullock points out that the agenda of the German women's movement for new housekeeping and that of the modernist architects' for new, simpler, and rationally restructured houses overlapped in 1920 serlin. The basis for the restructuring would be the domestic activities. That is why the new dwelling had to be designed from the inside out and starting from the functionally oriented service spaces, such as the kitchen. New housekeeping demanded excluding any equipment and activity besides food preparation from the kitchen. Having a single purpose helped 'standardising conditions', and made the kitchen space more calculable and compact. A compact kitchen, such as Frankfurter Küche, in turn, helped avoiding unnecessary and unforeseeable movement. The required movements were to be organised so as to follow the work process as much as possible, as in Frederick's kitchen layouts. In fact, while transposing the approach of Taylor, who dwelled more on temporal optimisation, to household tasks, Frederick made at least some of them more spatial. This inspired their use beyond the kitchen, in visualising a variety of movements and activities in Taut's book, which acquired further technical rigour in Klein's method. However, Frederick's flow diagrams delineating the simpler, more defined, and production-oriented tasks such as 'making an omelette' became more problematic and rather controversial when aimed to cover more domestic activities. Nevertheless, new housekeeping methods had an impact on the housing committees and policies of the time, and ultimately affected both housing and appliance production. ${ }^{18}$ Imprinted on modernist thinking and vocabulary, concerns and results of motion-based spatial efficiency arguably disseminated quite widely and had long-lasting effects. Robin Evans argued that the logic behind Klein's pathways, albeit attenuated, lives on, 'buried' in the regulations, codes, design methods, and rulesof-thumb that continue to effect housing production. ${ }^{19}$

There are many spaces where thinking through flowcharts and planning of user routes are not so much buried. It is easier to discern this in buildings accommodating activities that follow stricter protocols (such as medical or security conditions). But more commonly, the workings of most buildings that need to tackle a sizeable crowd depend on routing it smoothly. One can think of many examples from university cafeterias to sports arenas and larger performance halls. In transportation buildings such as subway stations or airports, the crowd not only needs to be steered, funnelled, or diverted, its movements also need to be orchestrated so as to accord to the routes of various machinery such as moving walkways, luggage conveyors, or trains. Besides human crowds, animal crowds are also made to move or carried along predefined paths that determine the spatial configuration of buildings like slaughterhouses and industrial farms. ${ }^{20}$ A wedding ceremony, as carried out in Turkey and explained above, follows a strict protocol that allows little, if any, room for customisation or improvisation. That is why it lent itself comfortably to spatial optimisation when necessitated by increasing demand. On the other hand, it is also conceivable that the pressure of the demand and the resulting time constraints contributed to the ossification of the ceremony. In any case, the spatiotemporal unfolding of the ceremony dominates the layout of the wedding hall. This makes it very easy to delineate the user routes in retrospect, even if there were none in the architects' drawings. Similarly, although there is no evidence that architects of this and similar halls were directly influenced by Weimar modernists, they were definitely benefiting from a modernist tradition of putting the plan together along lines of movement.

\section{Pressure of the masses}

The plan configuration of the wedding hall ensures the efficient and smooth succession of ceremonies. The crucial notion here is 'succession' - having to accommodate wedding after wedding - more than efficiency. This differentiates the layout of the wedding hall from any design effort that takes users' probable movements into consideration. The latter is all too common. Quite possibly all architects project imaginary figures into the devised architectural space, the idea being that the predicted experience and sensations of this figment of imagination would provide feedback for design. Moreover, architects and architecture students often make use of an 


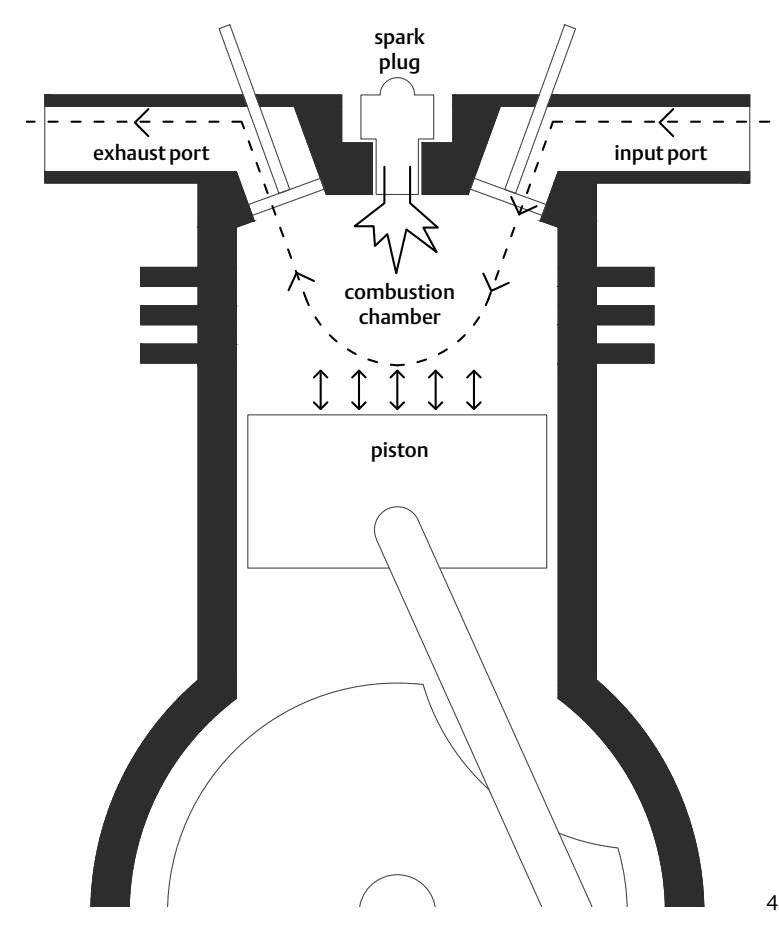

4 Diagram of the

piston of a

combustion engine.

imaginary walkabout to explain a design proposal. In the case of the wedding hall, however, the attention spent on the movement is more akin to streamlining the repetitive motion of a piece of machinery. It is the pressure of the fact that the machinery will have to perform the same motion over and over again. This demands careful calculation of each move so as to eliminate the risk of malfunction, which would affect many, not few. In a way, the functional diagram of the hall is not that dissimilar to that of the piston of an internal combustion engine [4]. In the piston, the fuel mixture is taken inside with an intake port, ignited by a spark plug, the combustion pushes the piston, after which the remains are discharged through an exhaust port as the piston comes back. But in the case of the wedding hall, exhausting takes more time than the intake and the event, so there are two exhaust ports in order to use the main chamber more efficiently.

This kind of pressure is inflicted on design by quantity, a specifically modern problem. It especially comes about when a building needs to be mass produced, as in the case of the rethinking of housing by early modernist architects, or when the building needs to tackle the masses, as in the case of the wedding hall. In both, people occupying the architectural space are conceived in their most generic characteristics. The inhabitants of Klein's apartments, for instance, are characterised by some of their most typical movements. Their individual or cultural identity does not really matter, and they are not differentiated from one another in terms of age and gender. Similarly, people partaking in the wedding are only conceived as a part of the crowd that they form. Their actions are governed by a process. They move along within the building as particles do in a piston. As do the couple, occupying one of the possible twenty-eight timeslots of the day. The repetitive and mechanistic flow of people renders them anonymous and turns individuals into massified subjects. Here, the two contexts, the mechanistic plan and the urban mass, overlap. They are obviously interconnected to begin with. A mechanistic plan presupposes the massified subjects. Offering any warranties as to how the architectural plan will efficiently accommodate the spatio-temporal unfolding of a task necessitates first rendering its users regular, uniform, and calculable to the degree that is required by the task and its planning. ${ }^{21}$ The repetitious character of the domestic chores, in the case of apartment optimisation, and the social codes and set protocols, in the case of the wedding hall, provided the architects with a degree of predictability.

Designing for mass demand has implications for the architect as well. The required or aspired level of rationalisation challenges the position of a selfcreating subject. ${ }^{22}$ The search for general principles, scientific methods, and objective techniques, an agenda shared by many of Klein's modernist contemporaries to varying degrees, does not presuppose a central, privileged position of authority for the architect. Rather than being the originating agent of form and meaning, here the architect is positioned more as an operator of rational methods. The efforts to rationalise architectural knowledge and formalise its procedures are not necessarily motivated solely by aspirations for functional efficiency or spatial optimisation. Such efforts also pre-date industrial production and the concentration of population in cities. ${ }^{23}$ These modern phenomena, nevertheless, further contributed to their momentum, instrumentalisation, and gaining wider currency.

Spatial optimisation for efficiency is integral to architectural practice today, whether it is buried or explicit. Its implementation does not need to stem from an outspoken theoretical position, or to be accompanied by a clear rhetoric. It is required, especially in cases of mass demand. Such demand and the techniques to meet it developed in the context of capitalist modernisation, seeming to connect the dots between the domestication of scientific management in the turn-of-the-century United States, mass housing research in Weimar Germany, and the coping strategies for tackling weddings in late twentieth-century Turkey. Concentration of population and its consequences are a binding commonality between modern cities of different eras and geographies that may otherwise look and feel quite different. Such concentration in cities began in the 1950 in Turkey, roughly a century after occurring in the leading industrialised European countries. ${ }^{24}$ In 1950, the population was twenty-one million, only a quarter of which lived in urban areas. By the year 200o, the population had not only more than tripled but also become dominantly urban. In the same fifty years, Istanbul's 
population grew tenfold to ten million. By 2015, it was around fifteen million. While Istanbul is the most striking case of this explosive increase in urban population, other major cities also received big waves of migration after 1950. Ankara was the exception in that it dramatically grew in the first half the twentieth century too. As a part of new regime's breaking away from country's imperial past and its seat of power, Ankara was declared the capital of the Turkish Republic in 1923. Not an especially significant town before then, the city centre had a population of slightly more than 20,000 in early $1920{ }^{25}$ The new capital grew steadily in the following decades. By 1950, the city centre reached 175,00o, and the greater Ankara region 620,000 inhabitants. In the second half of the century, the total population of the city grew more than sixfold to $4,000,000$. During the same fifty years, the annual number of marriages rose ninefold countrywide. ${ }^{26}$

\section{Emergence of a new building type}

It is no surprise, then, that purpose-built and dedicated wedding halls began to appear around the 1950s. In time, they gradually increased in number and became more adept at tackling the growing demand. The magnitude of the demand was a new phenomenon, yet its history was not necessarily much older. Before the republican revolution in 1923, officiation of marriages varied in the Ottoman Empire depending on the religious affiliation of the couple to be married. Marriages in the Muslim population were officiated by the qadi, the state appointed judge in the Ottoman judicial system. Local and appointed imams could also officiate, if a judge-issued marriage license was obtained. ${ }^{27}$ In any case, the official marriage was a rather private phenomenon, and did not involve an audience. ${ }^{28}$ In fact, it usually did not even involve the bride, as both parties may be represented by a legal guardian or

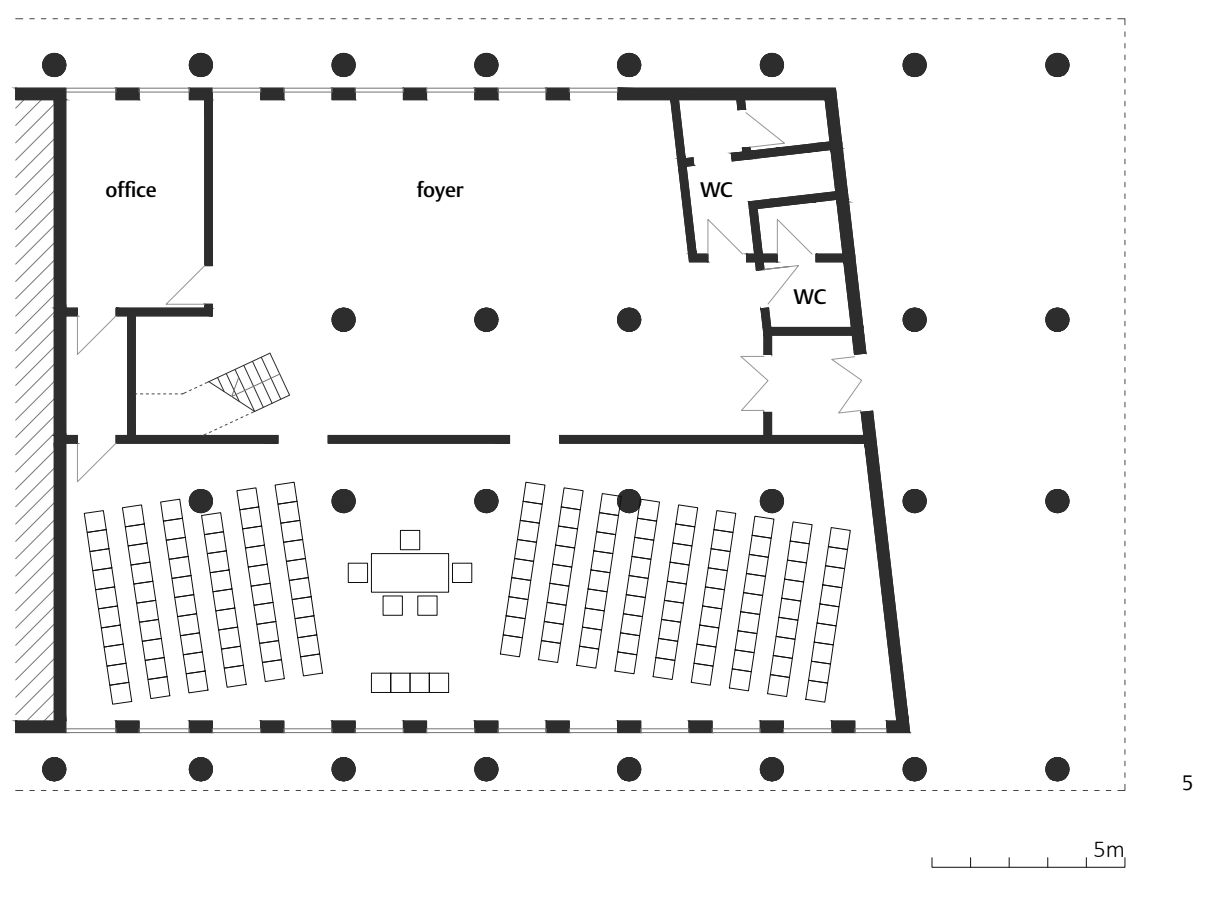

5 Partial ground floor plan of Nevzat Erol's winning scheme for Istanbul's municipality building project competition (1953).

6 Partial basement floor plan of the winning scheme for Konya's municipality building project competition (1957), by architects Doğan Tekeli, Sami Sisa and Metin Hepgüler.

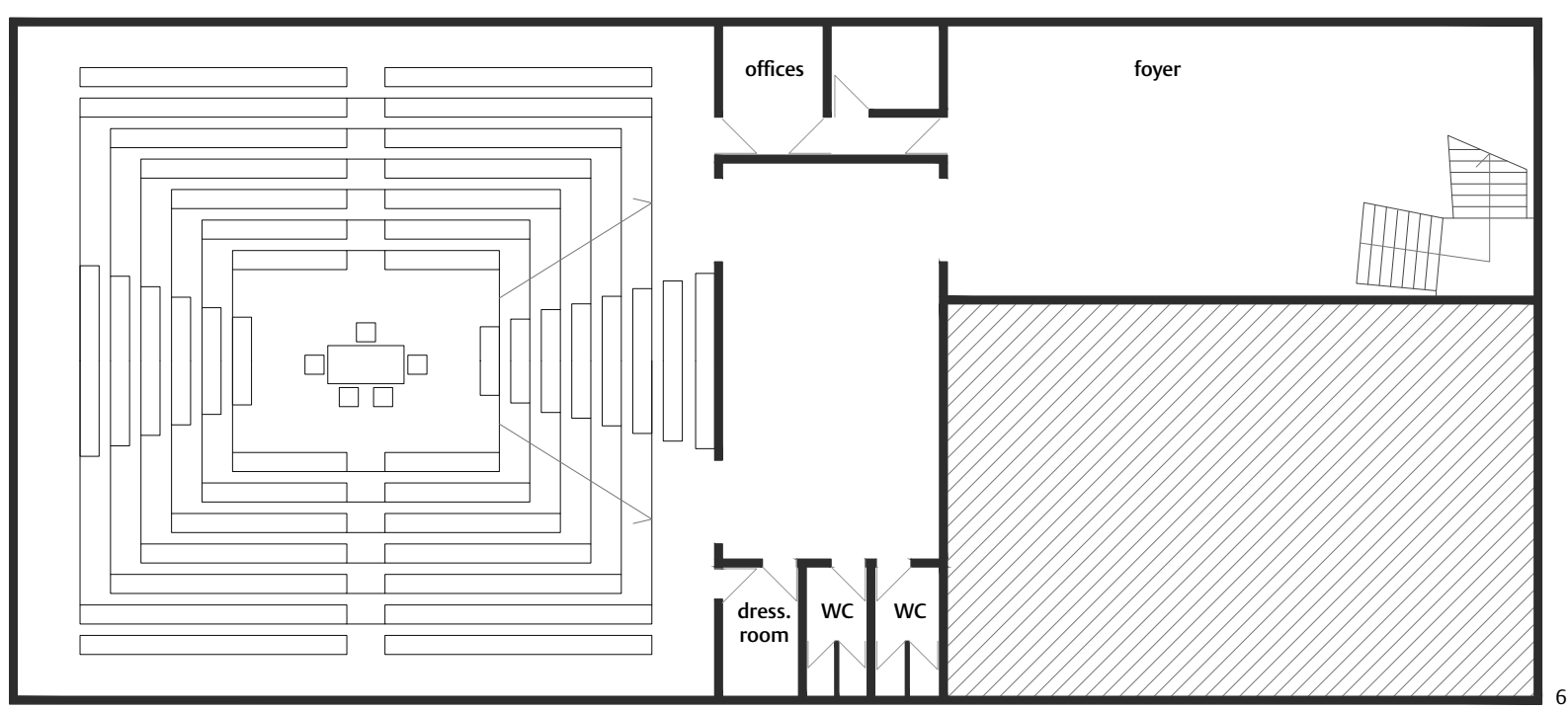


proxy, and this option was used for the bride quite often. ${ }^{29}$ The wedding officiation did not have any specific spatial requirements. An office or a room sufficed. Jews and Christians could choose to apply to qadis for marriage and divorce. Yet, high-ranking clerics of these faiths did have the authority to officiate marriages. In these communities, ritualistic temple marriages were also possible. Here, a larger audience could be present and the space of the temple was deployed in specific ways, in that parties occupied allocated spaces and followed predefined routes. ${ }^{30}$

For the majority of the population, an official wedding seems to become a ceremonial matter that required specific distribution of bodies in space only after the republican revolution. With the whole governance system changing, most local tasks in urban areas fell under the authority of the municipalities. The new and secular wedding ceremonies remained brief and mainly involved the couple affirming their decision in front of the marriage officer and witnesses. ${ }^{31}$ However, now there usually was an audience, especially in the cases where a separate wedding reception was not planned. The new ritual did not immediately become an architectural subject matter. Initially, it was more common to either use existing auditoriums for sizeable weddings or to refunction existing buildings as wedding and reception halls. In case of Ankara, for instance, the music hall in one of city's main parks, Göl Gazinosu, was repurposed as a wedding and reception hall, which served the city for a long time.

During and after the 1950s, however, one also sees an increasing number of purpose-built halls. In the early years, some were freestanding but most were part of new municipality buildings. In the winning and built scheme for the new Istanbul Municipality competition of 1953, the wedding hall occupied a part of the ground floor in the modernist block raised on pilotis. ${ }^{32}$ It was divided into two parts of similar size, the foyer and the auditorium [5]. The former was accessed by a single entrance on the recessed façade opening up to the podium underneath the bulk of the building. Although the hall was part of the main building, it operated independently. Other municipality projects from the same decade deploy similar, or even simpler layouts. In the winning project for the Konya municipality building competition, a separate entrance on the ground floor led to a staircase that descended to the foyer in the basement. This was the sole access to the hall, making it a dead end [6]. ${ }^{33}$

Most earlier halls comprised of a single foyer and a modest hall. The smaller halls were usually flat, so as to serve various purposes when need be. They did not involve differentiated user routes, specialised entrances, or multiple foyers. These earlier and conventional schemes presupposed a more comfortable scheduling of ceremonies. A new ceremony could not begin until the previous one had ended and the crowd left the building and its vicinity. Since there was just one point for both entry and the discharge, every movement route overlapped with itself and intersected with all the others. The couple used the same gate as everyone else. Making an entrance to an already populated hall would require arriving to the dressing room before the wedding but after the previous one, which was only possible with a more generous daily timetable.

In Izmir, freestanding wedding halls were already in place by the mid-1950s, when the hall in the municipality building started to fall short of meeting demand. Three of them were built in densely populated areas of the city due to the urgency and 'pressure' of the matter. ${ }^{34}$ The first strategy to cope with the increasing demand in rapidly expanding cities was to provide more halls in different parts of the city. Because they were freestanding and intended as multipurpose halls, the Izmir buildings were treated more freely in terms of their overall form and layout. Their foyers offered more opportunities than those squeezed into larger buildings. A decade later, one begins to see more projects where wedding halls are treated as separate or semi-autonomous parts of the municipality complexes. Obviously, there may be many reasons for such treatment, from site conditions to the thentrending fragmentary approach to architectural composition in Turkey. Yet the fact that plan schemes used in such projects deployed larger foyers surrounding the hall and differentiated entrance and exit doors demonstrates that the choice for freestanding buildings was intrinsically a functional one [7]. As the consequences of the increasing urban population began to be felt even more strongly in subsequent decades, wedding halls decidedly broke away from municipality buildings in major cities and their plans transformed so as to effectively tackle successive weddings.

A seminal project in this respect was the new wedding hall of Istanbul by Yaprak Karlıdağ [8]. This was a freestanding and purpose-built facility, constructed two decades after the competition for the main municipality building on its adjacent plot. This project diverged from previous schemes in two ways: (1) it clearly differentiated the routes of the couple and the guests; and (2) there were clearly separated entrance and exit foyers on either side of the main hall. In this way, not only did the route of the couple not intersect with that of the guests before the event, but more importantly, the route of a guest did not overlap with itself. Successive groups of guests could smoothly follow the same route without encountering each other at any point as in many of the earlier schemes. This is the first project that clearly provided a separate and specialised space for each step of the wedding process. Thus, one can easily match the temporal unfolding of the wedding with the spatial configuration in plan. The project was only published in a very succinct article. ${ }^{35}$ Yet even in the space of that brief report one sees how the pressure for enabling a hurried succession of weddings directed the design thinking. The architect operated with the assumption that the official wedding ceremony in the auditorium would be limited to a maximum of ten minutes, which is still more time than it usually takes today. That is why no seats were to be installed in the auditorium, except a 
few for the very old. The majority of the guests were expected to remain standing in front of benches. This way, it would require less time for people to settle and they could move along faster once the ceremony was over. It is possible to detect other measures to the same effect. All doors opened in the direction of the flow. Where stairs had often been deployed in the earlier schemes, here ramps were used to and from the foyers, enabling a smoother progression of people. Everything seems to be a part of a larger effort to ensure ordered and unhindered movement.
This layout broke away from the conventional auditorium towards a specialised wedding hall, yet there was still room for improvement. Although separate entrances were provided for the couple and the guests, their routes still intersected outside the building since the entrances were quite close to each other. More importantly, providing separate foyers for entrance and exit shortened the time required between two weddings to some extent, but intervals were still determined by the longest component of the wedding, the congratulations at the exit foyer.

\footnotetext{
7 Partial ground floor plan of the winning scheme for Erzurum's scheme municipality complex project competition (1957), by architects

Doruk Pamir, Kemal Aran.

8 Ground floor plan of Istanbul Municipality Wedding Hall by Yaprak Karlıdağ(1973).
}
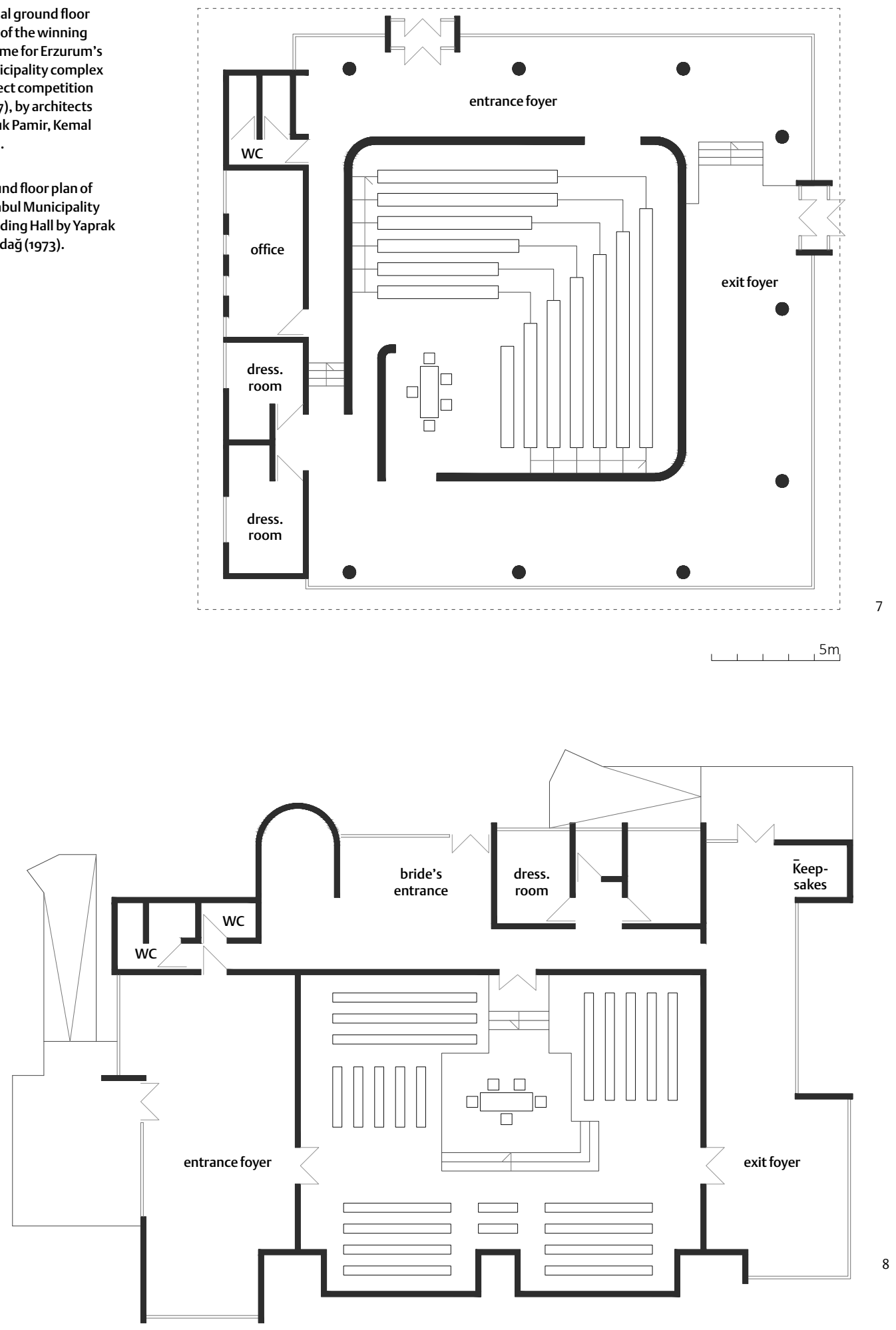
Another building, constructed almost two decades later, offered improvements on both of these issues. It was designed by the same architect on the other side of the Bosporus. ${ }^{36}$ The wedding hall in Kadıköy, designed in 1991, was the first building to deploy twin exit foyers, accomplishing another crucial break in the transformation towards a specialised layout [9]. In its preliminary design stage, it also had twin entrance foyers that were able to serve the guests of successive weddings separately. However, one large foyer was built in the end. In this building, the entrances for the couple and the guests were located at opposite sides of the building, further separating the route of the two prior to the wedding.

This building not only shows the efficiency pressure on wedding halls at the time of its design three decades ago but also gives an idea of the current state of things. Today, its twin exit foyers are further separated into two near-identical parts with retractable belt barriers, creating, in a rather rudimentary fashion, four exit foyers. This subdivision increases the efficiency of the main hall but results in significantly smaller exit foyers. To compensate for the constriction, the same kinds of barriers are used for regulating the line of guests waiting to congratulate the couple. Working at full capacity, these foyers resemble airport passport lines. This intense use is also made possible by some plan revisions. The offices were moved to a new building next door. The space was used to add more dressing rooms on the first floor and a secondary, small hall on the ground level. ${ }^{37}$ With its current state and use, a new wedding takes place every fifteen minutes in the main hall.

\section{Mass demand and architecture}

The urban condition in Turkey radically changed in the second half of the twentieth century. One might expect such change to deeply affect architectural thinking. After all, a comparable increase in urban population triggered significant architectural research in Europe and was intrinsically related to core issues of early modern architecture. The need to tackle the issues related to the growing urban population was a major factor in new design approaches that deployed modern materials and industrial construction techniques, invented modern housing types such as linear (zeilenbau) and point blocks of flats, and consequently rethought residential architectural plans and urban morphology. In Turkey, however, architectural design rarely dealt directly with the issues of people pouring into the cities. In the first decades of the mass movement towards cities, a significant part of the newly urban population sought shelter in squatter settlements (gecekondu) that fell outside of architects' professional field of operation. The remainder of the population mostly lived in apartment buildings individually produced on a single plot through the collaboration of the

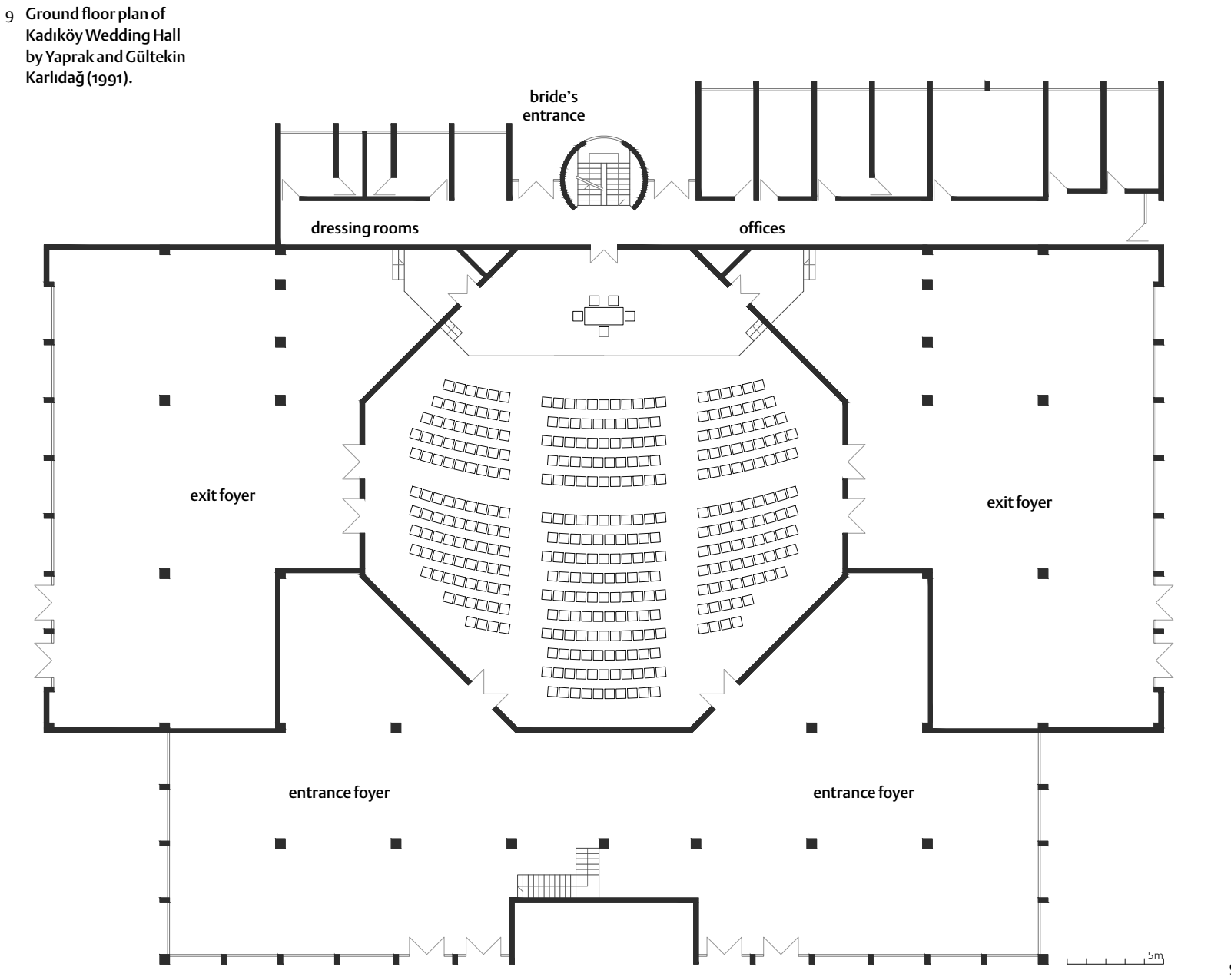


landowners and small contractors. This type of dwelling production was also outside the architects' reach for some time. As late as the mid-196os, only a third of residential projects was designed by architects even in major cities. ${ }^{38}$ Even then, not much of a design input was requested for these buildings as they usually duplicated a handful of layouts that contractors reckoned to satisfy the taste of the middle and upper-middle classes for which they were built. Up until the 1980s, these two types dominated the urban residential scene. There was no significant subsidised housing programme targeting lower income groups in a systematic way. No central governmental agency had to mass produce social or affordable housing on a significant scale. Consequently, there was no noteworthy architectural research on the optimisation of housing through strict efficiency concerns or mass production requirements. The Western discussion on the rationalisation of housework was followed in Turkey. ${ }^{39}$ Yet, unlike in Germany, it did not affect housing and appliance production directly, mainly because there were no comparable housing agencies or appliance industry by then. In short, it is possible to observe the rapid urbanisation of Turkey in its initial decades through housing, but more by the sheer quantity in which it was produced in rather than its architectural optimisation or modernisation of its production.

The effects of the rapidly growing urban masses seem to be more apparent in non-residential architecture. The governmental bodies may have had as little as possible to do with the housing problem, which in turn was solved by the new urban dwellers within their means. Yet, public amenities had to be provided by the government. This necessitated a systematic approach. Buildings that needed to be produced in cities throughout the country, such as schools and hospitals, were usually versions of the so-called 'typical' or 'standard' projects. Issued by the overseeing government agencies, these projects were either prepared in-house, or by architecture firms and architecture schools. There were also occasions where architectural competitions were held. Although the issue received much less attention than it should have in the very limited architectural press of the time, every now and then a competition, a new project, or a review of European practices appeared in journals and generated some discussion.

Key notions that guided the design of these typical projects, as one would expect, were reproducibility and adaptability. They were almost always modular so as to provide sufficient space for varying local requirements. Many school projects, for instance, had eight, twelve, or sixteen-classroom versions. On some occasions, as in the 'Expandable Hospital' design competition of $1976,^{40}$ rather than having different sizes for different sites, it was asked that the building could incrementally grow in size as the population inevitably increased. In both cases, buildings usually consisted of a core area that provided the services and wings that were facilitated by the core and stretched as needed. Regularity was always sought after. Most projects comprised of interconnected units instead of one large block, in order adapt better to sloping sites without much need for earthmoving or retaining walls. Some projects had alternatives for different climates since the country stretched over a relatively large geography with drastically different weather conditions.

Wedding halls, on the other hand, are more about tackling the masses than mass production or reproducibility. There were no institutional standard projects for them. Although the demand for this public service increased along with the population, people used wedding halls on much fewer occasions than schools and hospitals. Moreover, officiating marriages was the responsibility of the local authorities. No central governmental body had to produce this kind of building over and over again. That is also why the spatial innovations that increased the efficiency of this building type were not due to an accumulated institutional experience. Rather, they were the result of reflexive architectural design thinking; architects, burdened with the demand for faster weddings, improved on the existing schemes.

Marriage may long be romanticised by the mainstream culture. Yet, like any other public service that has to be offered to the masses, it is a matter of efficient management from the perspective of the institutions providing it. A few minutes are allocated for each wedding in today's busy city centres in Turkey. It was this pressure that turned the wedding hall design into a matter of optimisation, administration, even discipline. In its sophisticated examples, architects collapsed the procedure into components, timed these components, and came up with layouts that distributed and directed bodies in space to enable a fast service. The functional configuration of the buildings often dominated their design, thus similar layouts were able to resurface in projects of different decades, sites, and styles. The fact that specialised and purpose-built wedding halls did not exist before the period of rapid urbanisation makes them very distinctive in terms of bearing the traces of their historical period and social context. Having no established canon also arguably made it easier for the pressing concerns of the time to govern their layouts. The emergence of this building type and the transformations it underwent offer a rare insight into how the rapidly growing urban masses affected design thinking in architecture in Turkey. 


\section{Notes}

1. Archizoom, 'Città, Catena di Montaggio del Sociale: ideologia e teoria della metropolis [City, the Assembly Line of the Social: Ideology and Theory of the Metropolis]', Casabella, 350-1 (July to August 1970), 43-52 (pp. 43, 51); See Archizoom, 'No-Stop City, Residential Parkings, Climatic Universal System', in Domus, 496 (March 1971), 49-55.

2. The building was designed by the architects Nesrin and Affan Yatman between October 1991 and March 1992. It went through some revisions, mostly limited to the secondary spaces. Today, there is a small, secondary wedding hall in place of the wedding officer's room and some of the shops. There was also a recent refurbishment where finishing materials of the hall were renewed. It was originally called by the name of the borough it serves, Çankaya. It now bears the name of a previous mayor of the city of Ankara, Vedat Dalokay, who also was a prominent architect and is perhaps best known for his Faisal Mosque in Islamabad. Here, I used the original, shorter name mainly because it denotes the location of the building. The only published document on the building seems to be the brief entry in the 1992 catalogue of the Chamber of Architects' exhibition. See Mimarlar Odası, Ulusal Mimarlı Sergisi ve Ödülleri 1992 [National Architecture Exhibition and Awards 1992] (Ankara: Mimarlar Odası, 1992), p. 73

3. There is also an event and reception hall in the basement, which has a separate entrance. Here I only dwell on the wedding hall above ground level.

4. According to Turkish Statistical Institute data, the number of marriages in Ankara in July 2018 was almost four times that of January.

5. A well-known and often-cited early example on isolating the activities and routes of different users in domestic layouts is: Robert Kerr, The Gentleman's House; or, How to Plan English Residences (London: John Murray, 1865).

6. Klein published a report in $\mathbf{1 9 2 7}$, where he used this method to evaluate some housing schemes by J. J. P. Oud. This seems to be the first published version. See Alexander Klein, 'Versuch eines graphischen Verfahrens zur Bewertung von Kleinwohnungsgrundrissen [Attempt at a Graphical Method for the Evaluation of Small Apartment Floor Plans]', Wasmuths Monatshefte für Baukunst, 11:7 (1927), 296-8 $<$ https://digital.zlb.de/viewer/ readingmode/14192921_1927/314> [accessed 1 November 2019]. For a revised English version of the argument, see Alexander Klein, 'Judging the Small House', The Architectural Forum, 55 (August 1931), 166-72.

7. There were three criteria and the remaining two were: concentration of free areas, which was rendered visible by hatching the floor area free of essential furniture, and geometrical similarity and coherence of the plan's elements, which were simply shown by comparing the outlines of the rooms in a plan. In later iterations, other criteria were added. For a recent study that traces the different versions and contextualises Klein's method, see Christoph Lueder, 'Evaluator, Choreographer, Ideologue, Catalyst: The Disparate Reception Histories of Alexander Klein's Graphical Method', Journal of the Society of Architectural Historians, 76:1 (March 2017), 82-106.

8. The fact that Klein's pathways never cross each other, along with the separation of activities, was seen by Robin Evans as a part of an ongoing process through which domestic inhabitants were atomised, individualised, and separated. In his inspiring essay, Evans compared some of Palladio and Raphael's domestic layouts with some English house layouts from the late seventeenth century onwards. The former are open matrices of rooms with little or no specialised circulation spaces. There are many connections between the rooms, thus many possible routes, which, Evans argues, is appropriate to a society that 'feeds on carnality, recognizes the body as the person and where gregariousness is habitual'. In contrast, the latter plan type, deploying corridors and thus separating circulation and inhabited space, is appropriate to a society that 'finds carnality distasteful, sees the body as a vessel of mind and spirit, and in which privacy is habitual'. See Robin Evans, 'Figures, Doors and Passages', Architectural Design, 4 (April 1978), 267-78; reprinted in Translations from Drawing to Building and Other Essays (Cambridge, MA: MIT Press, 1997), pp. 54-91. For a critique of Evans's interpretation of Klein see Lueder, 'Evaluator'.

9. See drawings of Gray's Villa E.1027, designed with Jean Badovici, 'Maison en Bord de Mer', L'Architecture Vivante (autumn/ winter 1929), p. 23.

10. Bruno Taut, Die Neue Wohnung, Die Frau als Schöpferin [The New Dwelling,
The Woman as Creator] (Leipzig: Klinkhardt \& Biermann, 1924), pp. $72,73,76,77$.

11. Alexander Klein, 'Tagesfragen der Berliner Wohnungswirtschaft', Städtebau, 21:6 (1926), 90-104 (p. 93) <https://digital.zlb.de/viewer/ readingmode/16297425_1926/102> [accessed 1 November 2019].

12. Taut, Die Neue Wohnung, p. 64

13. Christine Frederick, The New Housekeeping: Efficiency Studies in Home Management (Garden City, NY: Doubleday, Page, 1913), p. 10.

14. For this reading of Frederick's drawing, see Paul Emmons, 'Intimate Circulations: Representing Flow in House and City', AA Files, 51 (winter 2005), 48-57 (p. 53).

15. Christine Frederick, Household Engineering, Scientific Management in the Home (Chicago, IL: American School of Home Economics, 1915).

16. See Frederick W. Taylor, Principles of Scientific Management (New York, NY: Harper \& Brothers, 1911); Frank B. Gilbreth, Primer of Scientific Management (New York, NY: D. Van Nostrand Company, 1914); Frank B. Gilbreth and Lillian M. Gilbreth, Applied Motion Study: A Collection of Papers on the Efficient Method to Industrial Preparedness (New York, NY: Sturgis \& Walton Company, 1917).

17. See Nicholas Bullock, 'First the Kitchen - Then the Façade', AA Files, 6 (May 1984), 58-67 (p. 6o). See Christine Frederick, Die rationelle Haushaltführung [The Rational Housekeeping], trans. by Irene Witte (Berlin: Springer, 1922); for a similar and popular German handbook, see also Erna Meyer, Der neue Haushalt, ein Wegweiser zu wirtschaftlicher Hausführung [The New Household, a Guide to Economical Housekeeping] (Stuttgart: Franckh'sche Verlagshandlung, 1931). Bullock also notes that Henry Ford's biography, published in Germany in 1924, became an immediate bestseller and sold over 200,ooo copies by the end of the decade.

18. Bullock, 'First the Kitchen', p. 63.

19. Evans, 'Figures, Doors and Passages', p. 85 .

20. Marco D'Eramo argues that the logic of 'assembly line' was first conceived in reverse by the American meat packing industry as the 'disassembly line', where pig carcasses 'run along a line suspended from a revolving rail, while workers stood still' and performed the same task over and over again. See Marco D'Eramo, The Pig and the Skyscraper: Chicago: A History of Our Future, trans. by Graeme Thompson (London: Verso, 2003), p. 28. 
21. Here I borrow and transpose a Nietzschean formulation. Nietzsche argued that the prerogative to make promises requires first 'making man to a certain degree uniform, a peer amongst peers, orderly, and consequently predictable'. Friedrich Nietzsche, On the Genealogy of Morality, II, p. 2

22. On the problematisation of the subject brought by rationalisation in the context of Weimar Republic, see K. Michael Hays, Modernism and the Posthumanist Subject: The Architecture of Hannes Meyer and Ludwig Hilberseimer (Cambridge, MA: MIT Press, 1992).

23. As exemplified, for instance, by Durand's studies. See Jean-NicolasLouis Durand, Recueil et parallèle des édifices de tout genre anciens et modernes (Paris, 1801) and Précis des leçons d'architecture données à l'École royale polytechnique (Paris, 1819) Also see Leandro Madrazo, 'Durand and the Science of Architecture', Journal of Architectural Education, 48:1 (September 1994), 12-24.

24. From 1850 to 1900 , the population of London grew threefold to 6,500,000; Paris grew two-and-ahalf-fold to 3,300,ooo; and Berlin grew five-and-a-half-fold to $2,400,000$. During the same period Istanbul, the most prominent Ottoman city, grew only $15 \%$ from 785,000 to 900,000 . After such dramatic events as two World Wars, the fall of the Ottoman Empire, and the declaration of the new republic, it was again around $1,000,000$ in 1950 (yet its ethnic and religious composition had dramatically changed). See Tertius Chandler and Gerald Fox, 3000 Years of Urban Growth (New York, NY and London: Academic Press, 1974), pp. 328-30.

25. Ali Cengizkan, Türkiye için Modern ve Planh bir Baskent Kurmak: Ankara 1920-1950 [Constituting a Modern and Planned Capital for Turkey: Ankara 1920-1950] (Ankara: GoetheInstitut, 2010) <http://www.goethe. de/ins/tr/ank/prj/urs/geb/sta/ trindex.htm> [accessed 1 November 2019].

26. Turkish Statistical Institute, Statistical Indicators 1923-2011 (Ankara: Turkish Statistical Institute Printing Division, 2012), p. 32.

27. Gotthard Jäschke, 'Türkiye'de "İmam Nikahı" ["Imam Marriage" in Turkey]', trans. by Ahmet Mumcu, in Sabri Sakir Ansay' in Hatırasına Armağan (Ankara: Ankara Üniversitesi Hukuk
Fakültesi Yayınları, 1964), pp. 11-32 (p. 16)

28. Now as well as then, apart from the official wedding, there are various kinds of customary wedding parties that take place both before and after the wedding, if the couple choose to have them. These often involve many rituals and traditions that vary in different regions of the country. There is also the possibility to have a wedding reception and ask the marriage officer to attend and officiate the wedding there. Yet the bulk of the official weddings take place in municipality buildings today.

29. M. Akif Aydın, 'Osmanlı Hukukunda Nikah Akitleri [Marriage Contract in Ottoman Law]', The Journal of Ottoman Studies, 3 (June 1982), 1-12 (p. 10).

30. In some countries, especially in the Balkans, it is possible to see the mosque space being used for religious weddings that involve an audience.

31. After municipalities took over the wedding officiation, the practice of affirming the marriage before a religious functionary continued as a personal preference. For the Muslim population, this came to be called 'imam marriage' and is not legally binding.

32. Nevzat Erol's winning scheme was published in 'İstanbul Belediyesi Binası Proje Müsabakası [Project Competition for the Istanbul Municipality Building]', Arkitekt, 259 (1953), 71-7. The building was realised in a rather long period of time and the built scheme involved modifications.

33. The architects were Doğan Tekeli, Sami Sisa, and Metin Hepgüler. The former two founded one of Turkey's first and most prolific architecture firms. The competition project is from 1957 , the building was built, with some revisions, by 1964 . See 'Konya Belediyesi Binası Proje Müsabakası(Project Competition for the Konya Municipality Building)', Arkitekt, 287 (1957), 58-6o.

34. It is the architects who use the expression of 'pressure' and specifically dwell on the urgency of the demand; see Riza Askan and Harbi Hotan, 'İzmir Belediyesi Evlendirme Dairesi, Eşref Paşa [İzmir Municipal Marriage Office, Eşref Paşa]', Arkitekt, 279 (1955), 76-7. The other two buildings were built in Kültürpark and Karşıyaka.

35. Yaprak Karlıdağ, ‘İstanbul Belediyesi Evlendirme Dairesi (Istanbul Municipality
Department of Marriage)', Arkitekt, 351 (1973), 117-20. This building was demolished in 2017.

36. The building was designed by Yaprak Karlıdağ with Gültekin Karlıdağ. According to the limited amount of records at Kadıköy mucipality, the project was approved by May 1991.

37. Moreover, new restrooms were added at two corners, serving the entrance and exit foyers. Omitting the restrooms in the basement and the staircase leading down to them resulted in a larger entrance foyer. These revisions and refurbishment were done in 2007 when the building underwent extensive retrofitting.

38. This is the average figure of Istanbul, Ankara, and Izmir. The rest was designed by civil engineers; see 'Sosyal Konut Standartları Üzerine Mimarlar Odasının Görüşleri [The Views of the Chamber of Architects Regarding Social Housing Standards]', Mimarlk, 9 (1964), 14-16 (p. 16).

39. This discussion was influential in shaping the curriculum of Girls Institutes in 1920s, and there were derivative publications on the issue in the 1930s. See Yael NavaroYașin '“Evde Taylorizm”: Türkiye Cumhuriyeti'nin Ilk Yillarında Evişinin Rasyonelleşmesi (1928-40) ["Taylorism at Home": The Rationalization of Housework in early Republican Turkey (192840)]', Toplum ve Bilim, 84 (spring 2000), 51-74.

40. 'Büyüyebilen Hastane Mimari Proje Yarışması [Architectural Project Competition for Expandable Hospital]', Arkitekt, 366 (1977), 86-91.

\section{Illustration credits}

arq gratefully acknowledges:

Emre Altürk, 1, 4-9

Christine Frederick, 3

Alexander Klein, 2

\section{Competing interests}

The author declares none.

\section{Author's biography}

Emre Altürk teaches design studio, architecture theory, urban history, and visual studies at Istanbul Bilgi University. He studied architecture at METU, Ankara, and received his $\mathrm{PhD}$ from TU Delft, where he also taught for six years.

\section{Author's address}

Emre Altürk

emre.alturk@bilgi.edu.tr

ealturk@gmail.com 